\title{
Pancasila: Ideologi dan Cabaran dalam Perkembangan Filem Indonesia
}

\author{
Firdaus el Hadi \\ University Malaya \\ firdauseh@gmail.com \\ Md Azalanshah Md Syed \\ University Malaya \\ azalan@um.edu.my \\ Hamedi Mohd Adnan \\ University Malaya \\ hamedi@um.edu.my
}

\section{PANCASILA: IDEOLOGY AND CHALLENGES IN INDONESIAN FILMS DEVELOPMENT}

\begin{abstract}
This qualitative study examines political ideology mainly on Pancasila and its association in the development of Indonesian films. Like other countries, Indonesia has undergone a change of political system from time to time. Indonesian Ideology and its political system evolved in three phases: Orde Lama (the old order), Orde Baru (the new order) and Orde Reformasi (the reformed order) that directly or indirectly form the narrative and plot of popular Indonesian films. As a policy of the nation-state, pancasila that emerged during the era of Orde Lama is influential not only to enlight the creation of national identity but to form popular views in various contexts including filmmaking. Thus, this study will analyse the importance of Pancasila as a major element in the making of popular Indonesian films and various challenges to maintain its role as important ideology for establishing the national identity of the state.
\end{abstract}

Keywords: Pancasila, films, New Order, Soeharto, Indonesia

\section{PENDAHULUAN}

Pancasila yang menjadi falsafah serta ideologi Indonesia tidak terbentuk secara langsung atau digubal oleh secara individu. Pembentukannya melalui suatu proses yang panjang dalam sejarah kewujudan bangsa Indonesia. Dengan perkataan lain, Pancasila sebagai suatu ideologi adalah bersumberkan budaya bangsa Indonesia. Proses pembentukan Pancasila telah digubal dan diperhalusi oleh para pendiri negara bangsa Indonesia. Namun begitu, 
nilai dan inti pati utama yang terkandung dalam Pancasila telah sedia wujud dalam masyarakat Indonesia itu sendiri, dan ini termasuklah adat istiadat, budaya warisan dan unsur keagamaan. Nilai-nilai ini kemudiannya telah diangkat para pendiri negara bangsa Indonesia dan diiktiraf oleh Jawatankuasa Persiapan Kemerdekaan Indonesia pada 18 Ogos 1945 sebagai teras kenegaraan yang penting (Kaelan, 2002: 13).

Dari segi sejarah, Pancasila merupakan suatu pandangan dan nilai dalam kehidupan rakyat yang telah wujud sebelum bangsa Indonesia dibentuk sebagai sebuah negara bangsa. Bangsa Indonesia telah berkembang dengan suatu identiti dan jati dirinya sendiri. Menurut M.Yamin (1962), negara kebangsaan Indonesia terbentuk melalui tiga tahap, pertama, ketika zaman Srivijaya di bawah pemerintahan Wangsa Syailendra $(600 \mathrm{M})$ yang bercirikan pemerintahan berkerajaan; kedua, negara kebangsaan zaman Majapahit (1293M-1525M) yang bercirikan pemerintahan beraja; dan ketiga, negara kebangsaan moden iaitu Indonesia yang merdeka (Kaelan, 2015: 49). Perisytiharan kemerdekaan Indonesia boleh dianggap sebagai suatu perubahan besar dalam konteks kehidupan masyarakat Indonesia (Geertz, Mahasin, \& Rasuanto, 1983a). Geertz (1983b) menyatakan bahawa rakyat negara-negara baharu terbentuk akan didorong oleh dua jenis motif yang kuat dan saling mempengaruhi. Yang pertama ialah pembentukan identiti nasional supaya Indonesia dipandang dan mendapat perhatian negara lain di dunia manakala kedua ialah kehendak untuk membina suatu negara moden yang efisien dan dinamik bagi mencapai kemajuan, peningkatan taraf hidup yang pada masa yang sama membentuk sistem politik, keadilan sosial yang lebih meluas dan peranan di peringkat antarabangsa (Sudaryanto, 2007: 15).

Budaya kebangsaan ialah hasil pemikiran bersama rakyat Indonesia. Namun, kebudayaan lama tetap diamalkan dan dipelihara dalam budaya kebangsaan Indonesia. Perkembangan kebudayaan harus mementingkan pemeliharaan ketamadunan, kebudayaan dan perpaduan bangsa di samping menerima masuk budaya asing bagi memperkaya dan mengembangkan budaya nasional bangsa Indonesia (Muhammad Yamin, 1959: 44). Sebagai contoh, Orde Baru Pancasila telah dikembangkan menjadi suatu ikon pemerintahan. Malahan, pengaruh Pancasila telah dibuktikan melalui pengaruhnya yang begitu kuat sehingga penentangan terhadapnya akan dianggap sebagai suatu kesalahan yang besar. Pada suatu tahap, Pancasila telah dimanipulasi untuk tujuan politik oleh para ahli politik Orde Baru. Keadaan ini mendorong lahirnya anggapan bahawa sebarang perlakuan untuk mengembangkan dan mengkaji Pancasila adalah usaha mengembalikan kewibawaan Orde Baru (Kaelan, 2015: 21).

Soeharto memandang Pancasila sebagai suatu falsafah hidup. Keunikan Indonesia tergambar dalam pemerintahan Orde Baru. Adam Malik, bekas wakil Presiden Indonesia, menyatakan meskipun Pancasila diciptakan semasa kemerdekaan, pada era pemerintahan Soeharto (sejak 1965) mulai berbentuk dan konsisten apa-apa yang diinginkan pada era pemerintahan awal Soekarno. Adam Malik, bekas wakil Presiden Indonesia menyatakan meskipun Pancasila diciptakan ketika Zaman Soekarno, iaitu semasa awal kemerdekaan Indonesia, konsepnya digunakan secara konsisten ketika era pemerintahan Soeharto. Beliau merujuk pada Ketetapan MPRS no. XX sebagai bukti bahawa Pancasila sememangnya merupakan sumber hukum yang sah, bermoral, kekuasaan dan undang-undang tertinggi di Indonesia. Pancasila tidak dapat dilaksanakan apabila terdapatnya unsur bangsa yang tidak sesuai dengan keperibadian nasional. Sebagai contoh, ideologi asing yang wujud dalam kalangan parti politik pembangkang seperti yang berlaku di Barat (Ramage, 2002: 14). Pemerintahan Orde Baru ialah suatu rejim pemerintahan yang menekankan kemurnian 
ideologi. Justeru, Pancasila telah menjadi ideologi nasional dan warganegara Indonesia wajib mempelajari dan memahaminya dalam konteks kehidupan seharian. Kursus Pancasila perlu diambil oleh semua penjawat awam dan pelbagai kumpulan lain manakala semua organisasi politik dan sosial telah diwajibkan mengamalkan pancasila sebagai dasar tunggal mereka. Mereka yang mempersoalkan Pancasila disamakan dengan tindakan penentangan dan cubaan menjatuhkan sistem tersebut dan boleh dikenakan hukuman tahanan penjara (Budiman, 1990: 116).

Perubahan dan pencarian identiti nasional bangsa Indonesia dilihat sama seperti perubahan nasionalisme yang berlaku di negara-negara Barat. Transisi perubahan dapat dilihat sejak awal abad ke-20 apabila fahaman Nasionalisme Budaya (Cultural Nasionalism) kepada Nasionalisme Politik (Political Nasionalism) yang dilihat sebagai nasionalisme moden. Indonesia yang berkembang daripada suatu kesedaran pelbagai elemen sosial budaya, kepelbagaian budaya, kelompok, etnik, ras, golongan, dan juga kepelbagaian agama menentukan kesamaan pandangan, cita-cita, dan tujuan dalam suatu kehidupan kebangsaan dan kenegaraan Indonesia (Kaelan, 2015: 239). Ideologi Pancasila dipertahankan bagi tujuan untuk menjaga identiti nasional. Hal ini dapat dilakukan dengan dua cara, iaitu dari segi dalaman dan luaran. Dari segi dalaman, Pancasila ialah dasar yang memerlukan setiap individu berpegang teguh padanya. Dari segi luaran, Pancasila tidak boleh dicampurkan dengan nilai-nilai yang bertentangan dengan nilainya. Terdapat lima prinsip Pancasila: (1) Ketuhanan yang Maha Esa; (2) Kemanusiaan yang adil dan beradab; (3) Persatuan Indonesia; (4) Kerakyatan yang dipimpin oleh hikmat kebijaksanaan dalam permesyuaratan perwakilan; (5) Keadilan bagi seluruh Rakyat Indonesia.

Dalam menyusun Pancasila, bangsa Indonesia mengetahui bahawa mereka sedang mengembangkan suatu paradigma baharu untuk memahami semua aspek budaya dan model baharu bagi masyarakat demokratik. Mereka menolak pandangan enlightment worldview dan pandangan hak individu dan kolektif lalu menggantikannya dengan keyakinan berteraskan keagamaan. Seperti yang disarankan Whitehead, Jung, dan Laszlo (Beck \& Irawan, 2016) mereka memfokuskan aspek paling universal, humanistik, dan umum daripada enam tradisi keagamaan dominan yang dipraktikkan oleh warga negaranya. Penulisan mereka dalam sebuah dokumen menyatakan pendapat yang menganggap setiap warga yang mempunyai pegangan agama dapat hidup bersama dengan aman dan damai walaupun mempunyai fahaman agama dan menganuti agama yang berbeza. Oleh hal yang demikian, pada 1 Jun 1945 Soekarno telah memperkenalkan Pancasila dengan visi bahawa falsafah dan fahaman Pancasila dapat menjadi medium penyatuan rakyat Indonesia yang berbilang budaya dan bangsa. Prinsip-prinsip Pancasila dapat meredakan konflik antara agama dan politik yang ada di Indonesia. Hal ini demikian kerana Pancasila menekankan kemajmukan dan toleransi antara penganut agama yang berbeza dan seterusnya meletakkan Pancasila sebagai satu kepentingan dalam konstitusi negara (Steenbrink, 2015).

\section{FILEM INDONESIA: SEJARAH DAN PERKEMBANGAN}

Pada penghujung tahun 1900, masyarakat Hindia Belanda sudah boleh menonton filem, atau lebih dikenali sebagai gambar bergerak dalam konteks Indonesia pada ketika itu. Rakyat Indonesia mula menikmati teknologi ini hanya selepas lima tahun penciptaannya oleh Amerika Syarikat, Perancis dan Inggeris. Pada tahun-tahun awal, pertunjukan pawagam belum memiliki tempat yang tetap dan lokasi tayangannya sering berpindah randah dari 
satu tempat ke tempat yang lain. Setelah tontonan filem dipertunjukkan di pusat pawagam yang tetap, muncullah kelas-kelas bioskop dan kelas-kelas penonton, seperti di Jakarta terdapat pusat pawagam khusus untuk kalangan warga Eropah, yang dipisahkan dengan warga peribumi (Biran, 2009: 30).

Pada mulanya, bioskop atau pawagam di Indonesia dimiliki sepenuhnya oleh orang Eropah. Namun apabila pawagam mula mewujudkan keuntungan dan menarik banyak penonton, perniagaan ini telah menarik minat orang Cina. Pada dekad 1920-an, pawagampawagam sudah memiliki lokasi yang tetap, namun pada tahun 1925 sebahagian pawagam telah dimiliki oleh orang Cina lantaran pemilikan modal yang kuat (Abdullah, Ardan, Biran, \& Dewan Film, 1993: 51). Pembikinan filem Indonesia pertama dapat dilihat pada tahun 1926, iaitu melalui filem Loetoeng Kasarung (1926), filem bisu yang berdasarkan cerita legenda Sunda yang sering ditampilkan dalam bentuk pertunjukan wayang atau sandiwara (Aartsen, 2011). Perusahaan filem pertama ialah N.V Jawa Filem Company yang didirikan oleh L.Heuveldorp dari Batavia dan G Krugers dari Bandung. Perusahaan ini mendapat sokongan dan bantuan besar daripada Bupati Bandung Raden Aria Adipati Wiranatakusumah V. Malahan para pelakonnya merupakan sepupu dan saudara-mara Bupati. Mereka berpendidikan tinggi dan fasih berbahasa Belanda (Abdullah et al., 1993: 83).

Selepas pembikinan filem tersebut, etnik Cina banyak memainkan peranan dalam perusahaan filem di Indonesia. Antara syarikat filem Cina yang lahir di Hindia Belanda ialah The South Sea Film yang diusahakan oleh Liem Goan Lie dan Tjoen Lian. Filem pertama mereka ialah Lily Van Jawa (1928) yang mengisahkan seorang gadis yang dijodohkan secara paksa dengan seorang pemuda pilihan keluarga. Filem ini digarap oleh Wong Brothers yang berhijrah daripada industri filem Shanghai ke Indonesia. Wong bersaudara pada akhirnya mendirikan perusahaan filem sendiri, iaitu Halimoen Films (Abdullah et al., 1993: 84).

Terdapat beberapa faktor mengapa komuniti ini mengambil alih produksi filem di Indonesia. Pertama, kebanyakan pemilik pawagam dan pengeluar modal serta penonton ialah masyarakat Tionghoa. Kedua, pusat pawagam pada ketika itu sudah terlebih dahulu didominasi dengan filem import, termasuklah filem Mandarin. Ketiga, pementasan bangsawan masih bersifat tradisional pada umumnya dan hanya menayangkan kisah dongeng dan tidak sesuai dengan realiti. Kesannya, seawal tahun 1937, kebanyakan pelakon bangsawan mula mengambil bahagian dalam perusahaan filem walaupun mereka mempunyai kedudukan sosial yang rendah pada mata masyarakat (Said, 1991a: 17).

Pada tahun 1937, Albert Balink muncul sebagai pengarah dan menghasilkan filem Terang Boelan manakala Wong bersaudara pula bertindak sebagai pengarah sinematografi bagi filem tersebut. Filem ini merupakan filem Indonesia bersuara pertama dan sengaja dihasilkan untuk meraih kejayaan secara komersial. Filem ini merupakan tiruan filem Hollywood yang bertajuk The Jungle Princess yang dibintangi Dorothy Lamour. Bagi menarik perhatian penonton, Terang Boelan menggunakan lagu popular Indonesia. Filem ini sesuai dengan cita rasa orang ramai dan turut memberikan ilham dan semangat kepada mereka. Filem tersebut merupakan suatu kejayaan besar dan popularitinya mencakupi hingga Semenanjung Malaysia sehinggakan lagu “Terang Bulan”, menjadi sangat popular (Biran, 2009).

Filem ini menyuarakan kritik atas nilai-nilai tradisional yang melarang pernikahan antara pasangan muda. Naratif Terang Bulan hampir seluruhnya berkembang dengan latar belakang negeri asing seperti Singapura dan Malaya yang glamour dan tidak menyentuh 
citra kehidupan masyarakat di Pulau Jawa. Justeru, filem Terang Bulan dianggap sebagai filem cetak biru oleh para pengamal filem Indonesia meskipun kejayaannya menarik perhatian khalayak penonton yang besar (Krishna Sen, 2009:. 27). Namun demikian, filem ini tidak terlepas daripada kritikan khasnya dalam kalangan pengarah seperti Teguh Karya yang beranggapan bahawa Terang Bulan adalah suatu naskhah bersifat stereotype kepada industri dan teknik perfileman juga masih lagi lemah (Heider, 1991).

Kehadiran Jepun juga mempunyai impak terhadap industri perfileman Indonesia. Pada awal, kehadiran mereka disambut baik oleh bangsa Indonesia. Namun demikian, tindakan tersebut memakan diri apabila kehidupan menjadi lebih sukar kerana Jepun mengeksploitasi rakyat dan sumber daya alamnya. Minat Jepun kepada industri filem di Indonesia hanya untuk menyebarkan propaganda perang. Terdapat beberapa perubahan yang terjadi kepada industri filem di Indonesia. Pertama, pembikin filem dari Eropah dan China digantikan kepada orang Indonesia yang mendapat pengawasan sepenuhnya daripada pihak Jepun. Jepun tidak terlalu mementingkan unsur romantik dalam filem, sebaliknya lebih mengutamakan filem sebagai media untuk menyampaikan mesej politik dan ideologi mereka.

Seperti yang berlaku terhadap pemilikan tanah yang dikecilkan terhadap orang Tionghoa dan Belanda di Indonesia, bidang perfileman juga dihadkan dengan memberikan keutamaan kepada penyertaan etnik peribumi. Tindakan ini memberi manfaat dan pengalaman yang hebat bagi orang tempatan. Jika dibandingkan dengan para pembikin filem Tionghoa di Indonesia, orang Jepun memiliki pengetahuan teknik filem yang lebih baik serta organisasi produksi yang lebih besar. Maka dengan itu, perkara ini telah memberikan manfaat besar pada warga tempatan dalam pergerakan perjuangan mereka menerusi filem (Sen, 2009).

Pembelajaran mengenai selok-belok perfileman ketika pendudukan Jepun telah memberikan peluang dan ruang yang cukup besar kepada 'orang-orang filem' di Indonesia. Mereka mula bekerja secara sistematik dan menggunakan pelbagai teknik penggambaran yang lebih baik. Tidak seperti bekerja dengan orang Cina yang sering berkira terhadap aspek kewangan, orang Jepun bersikap lebih terbuka dan menyokong mereka. Malah, menurut Anjar Asmara, salah seorang pengarah terkenal pada masa itu, penjajahan Belanda hanya menekankan kepentingan untuk meraih keuntungan dengan mengimport filem dari Amerika (Said, 1991b).

Ketika Jepun menjajah Indonesia, mereka melakukannya dengan program pendidikan umum dan fizikal yang memberikan pengaruh besar dalam industri perfileman. Filem digunakan sebagai alat untuk menyebarkan propaganda dan penghormatan kepada negara. Ini menyebabkan pembikinan filem tempatan tidak menjadi kenyataan kerana hampir seluruh masa pendudukan Jepun digunakan untuk menghasilkan filem propaganda. Namun, pentingnya pendudukan Jepun terhadap dunia filem Indonesia bukan pada jumlah filem yang dihasilkan, tetapi pada kemunculan sikap atau kesedaran pembikin filem yang berubah secara radikal berbanding zaman sebelumnya (Said, 1991b).

Setelah Agresi Militer Belanda II mengambil alih semula Indonesia pada tahun 1948 dan keadaan dalam negeri kembali stabil, perusahaan filem mula bercambah kembali. Antara usaha awal telah digerakkan oleh Usmar Ismail yang lebih dikenali sebagai Bapa Perfileman Nasional. Sehubungan dengan itu, 30 Mac 1950 diisytiharkan sebagai Hari Perfileman Nasional mengambil sempena hari filem pertama Usmar Ismail 'Darah dan Doa' 
memulakan proses pembikinannya (Sen, 2009). Usmar Ismail berasal daripada keluarga aristokrat di Bukit Tinggi (Sumatra Barat). Beliau bersekolah di Jawa dan dikenali sebagai penulis lakon teater yang berbakat. Ketika Jepun menjajah Indonesia, beliau bekerja di bahagian propaganda dan ditugaskan untuk naskhah dan perkara yang berkaitan dengan penyebaran propaganda Jepun. Filem Darah dan Doa merupakan filem pertamanya di bawah produksi Perusahaan Filem Nasional (Perfini) - sebuah perusahaan yang didirikannya bersama Rosihan Anwar. Filem ini dianggap sebagai prototaip filem nasional dengan meletakkan prinsip-prinsip tertentu dalam pembikinan sebuah kisah dalam filem. Malahan kewujudan naratif nasionalis dalam ruang lingkupnya dan telah mendorong beliau untuk cenderung menceritakan perjuangan ketenteraan yang merupakan inti pembentukan Indonesia moden (Khoo, 2011: 11).

Kekuatan filem Darah dan Doa terletak pada kejujurannya. Meskipun filem ini mendapat reaksi keras daripada pelbagai pihak, proses pembikinannya membolehkan Usmar Ismail bebas memaparkan apa-apa yang diingininya. Antaranya termasuklah pemaparan tentang masyarakat yang terseret dalam kancah revolusi (Said, 1991b). Filem-filem arahan Usmar Ismail untuk Perfini selain Darah dan Doa termasuklah Enam Djam di Jogja (1950) dan Lewat Djam Malam (1954). Kesemua filem tersebut menceritakan kejadian pada empat tahun pertama selepas kemerdekaan. Filem-filem ini banyak dipengaruhi kaedah neo-realist yang popular dalam kalangan pembikin filem Itali yang meletakkan campuran aktor dan bukan aktor sebagai perwatakan penting dan sebahagian dialognya dilaksanakan secara spontan ketika penggambaran berlangsung. Namun begitu, berbeza dengan filem Itali, filem hasil sentuhan Usmar Ismail lebih menonjolkan unsur drama seperti yang dilihat dalam Lewat Djam Malam yang mengisahkan kehidupan watak utamanya, seorang pejuang kemerdekaan dan kembali menjalani kehidupan normal dalam masyarakat (Hanan, 2017: 66).

Era Orde Lama atau dekad-dekad pascamerdeka diwarnai lambakan filem Indonesia yang ditayangkan di pawagam berbanding era sebelumnya. Namun, tidak lama selepas itu khasnya ketika sentimen anti Amerika memuncak di Indonesia, Bachtiar Siagian yang merupakan salah seorang pengarah filem terkemuka telah menuduh wujudnya monopoli modal besar oleh Hollywood. Ini terbukti dengan kewujudan 11 perusahaan besar yang bergabung dan dikenali dengan nama AMPAI (Sen, 2009). Pada tahun 1955 bermulanya tindakan penentangan terhadap filem Hollywood dan telah mencapai puncaknya pada tahun 1964. Hal ini terjadi akibat keadaan politik negara yang tidak stabil pada ketika itu.

Pada tahun 1964, industri filem menjadi arena yang penting bagi pejuang nasionalis yang radikal. Kesannya, filem semakin menonjol dan berbaur politik. Pemulauan filem ialah puncak perjuangan tertinggi dalam kempen melawan kebudayaan Amerika dan isu itu dikemukakan oleh Soekarno dan Partai Komunis Indonesia (PKI). Isu yang pada awalnya adalah propaganda telah diubah oleh PKI menjadi salah satu strategi politik. Pada ketika itu, kedudukan PKI dan penyokongnya menjadi semakin kuat. Terdapat 158 judul filem yang dihasilkan Indonesia antara tahun 1957 sehingga terjadinya Pemberontakan G-30 S PKI pada tahun 1965. Seperti yang dilaporkan, 28 buah filem telah dihasilkan oleh pembikin filem berhaluan kiri dan filem yang paling menonjol ialah karya Bachtiar Siagian. Namun, filem-filem tersebut tidak menunjukkan realisme sosial seperti yang diinginkan berdasarkan ideologi mereka (Said, 1991a).

Kejatuhan Soekarno dan PKI pada era Orde Baru telah merangsang perkembangan yang lebih positif kepada industri filem Indonesia. Pada tahun 1970, sejumlah 17 filem telah meningkat kepada 124 buah filem pada tahun 1977 (Aartsen, 2011). Pada tahun 
yang sama, Badan Sensor Filem Indonesia (LSF) telah mengeluarkan satu panduan dan larangan keras terhadap sebarang pembikinan filem yang memaparkan unsur terlarang termasuklah seks dan kekerasan, elemen kolonialisme, imperialisme, fasisme, sosialisme dan komunisme. Dalam pada itu, tindakan mempolitikkan panggung wayang di Indonesia bukanlah suatu hal yang baharu. Perbezaan utama antara rejim Soeharto dengan Soekarno ialah isu keselamatan negara atau ketenteraman awam. Ketika era pemerintahan Soekarno, beliau lebih menekankan polisi menjaga kebudayaan nasional daripada pengaruh asing manakala idea Seoharto tentang keselamatan negara termaktub dalam peraturan filem tempatan. Filem tempatan haruslah taat kepada konsep Bhinneka Tunggal Ika, iaitu penyatuan dalam kepelbagaian; dan segala hal yang boleh menyebabkan pergolakan sosial perlu dielakkan. Soeharto juga telah mengamalkan dasar buka pintu terhadap filemfilem daripada Hollywood. Malahan, filem import tidak dianggap sebagai sesuatu yang berbahaya walaupun menyentuh isu Suku, Agama, dan Ras (SARA).

Sisi negatif dalam tempoh ini lebih menjurus kepada isu pembikinan filem propaganda yang dibiayai oleh kerajaan dan diarahkan oleh pengarah tertentu seperti Arifin C. Noer. Namun begitu, filem propaganda ini terarah kepada usaha meningkatkan imej Presiden Soeharto sebagai wira kebangsaan selepas kemerdekaan dan mewujudkan ketakutan terhadap komunisme. Filem-filem ini dihasilkan oleh Perum Produksi Filem Negara(PPFN) dengan G Dwipayana sebagai produsernya, yang dianggap rapat dengan Soeharto. Antara filem yang memaparkan imej positif Soeharto ialah Serangan Fajar (1981), yang menceritakan peranan Soeharto ketika proses kemerdekaan Indonesia. Selain itu, filem Pengkhianatan G-30 S PKI (1984) memberi gambaran kekejaman PKI. Filem ini tidak hanya ditayangkan di pawagam, tetapi turut ditayangkan di sekolah-sekolah dan stesen televisyen nasional, TVRI. Filem lain adalah Djakarta 1966 (1988) yang menceritakan perikatan antara mahasiswa dan Soeharto yang mewujudkan Supersemar (Surat Perintah Sebelas Maret), iaitu suatu deklarasi dan pengiktirafan bagi memberikan kekuasaan kepada Soeharto (Hanan, 2017: 82).

Filem Pengkhianatan G-30 S PKI merupakan bukti kuatnya penguasaan tentera di bawah kepimpinan Soeharto. Filem ini ditayangkan berulang kali pada setiap tahun di televisyen hingga berakhirnya pemerintahan Soeharto. Kesimpulan daripada filem-filem sejarah era Orde Baru dapat dilihat pada pidato Soeharto pada awal tahun 1980 yang menyatakan bahawa ancaman nasional muncul dalam pelbagai bentuk: "Marxisme, leninisme, komunisme, sosialisme, marhaenisme, nasionalisme, atau agama". Orang awam melihat bahawa filem-filem propaganda merupakan jawapan atas semangat nasionalisme yang ditonjolkan pada era Orde Baru (Sen, 2009: 180). Pawagam pada era Orde Baru diberi perhatian dan dikawal ketat sebelum filem-filem dapat ditayangkan (Paramaditha, 2012). Selain perlu melalui lembaga penapisan, ia perlu juga melalui tahap pre-censorship (pratapisan). Sebelum sesebuah filem memulakan penggambaran, skrip harus diserahkan untuk mendapatkan persetujuan daripada Direktorat Filem yang berada di bawah Jabatan Penerangan. Kadangkala lembaga tersebut memberikan arahan kepada pembuat filem untuk membaiki bahagian filem yang dianggap tidak sesuai, agar filem tersebut melepasi peringkat saringan penapisan.

Pada awal tahun 1990-an, filem Indonesia mengalami kemunduran. Perbezaan ini dilihat amat ketara kerana hanya tiga buah filem terhasil pada tahun 1999 berbanding 115 pada tahun 1990 (Aartsen, 2011: 9). Hal ini demikian kerana terdapatnya kemasukan dan dominasi filem Hollywood di samping kemunculan saluran televisyen swasta. Sebelum ini, rakyat Indonesia hanya bergantung pada satu saluran televisyen kerajaan, iaitu TVRI. 
Dominasi filem import terjadi kerana pembukaan jaringan pawagam Cinema 21 oleh Sudwikatmono, yang kebetulan merupakan sepupu Soeharto. Kebanyakan filem dihasilkan secara komersial yang dibiayai oleh sekumpulan kecil pemilik filem dan berunsur seram sensasi atau berbaur dengan unsur seks atau kedua-duanya.

Selepas pengunduran Soeharto dalam politik, secara perlahan produksi filem nasional mengalami peningkatan. Dekad 2000-an menyaksikan jumlah pembikinan filem meningkat daripada 11 buah filem setahun kepada 80 buah filem, dan mencapai kemuncaknya pada tahun 2008 dengan 91 filem telah dihasilkan (Aartsen, 2011: 10). Pembikin filem bebas (independent) antara yang memainkan peranan penting dalam kebangkitan industri perfileman Indonesia. Filem Kuldesak yang dihasilkan pada tahun 1998 merupakan filem pertama yang memperlihatkan peranan golongan muda dalam membawa perubahan pada industri perfileman di Indonesia (Yngvesson, 2015). Filem yang dihasilkan oleh karyawan seperti Riri Riza, Nan Achnas, Rizal Mantovani dan Mira Lesmana tidak menggunakan cara yang lazim yang ditetapkan oleh kerajaan. Hal ini demikian kerana mereka tidak mendaftarkan perancangan produksi dan menjadi anggota Karyawan Filem Televisi (KFT), yang merupakan syarat pembikinan filem dalam era Orde Baru. Justeru, mereka menjadi perintis dalam gerakan pembikinan filem bebas serta menjadi pendorong kepada pembikin filem generasi baharu.

\section{PANCASILA DAN FILEM NASIONAL}

Lima prinsip Pancasila ketika era pemerintahan Soekarno telah diterima secara umum meskipun mendapat tentangan daripada organisasi tertentu seperti Darul Islam. Penentangan ini berlaku kerana rukun atau Sila yang pertama iaitu "Ketuhanan Yang Maha Esa", iaitu kesediaan kerajaan Indonesia untuk memperakukan kesaksamaan terhadap agama lain selain Islam termasuklah Kristian, Hindu dan Buddha manakala rakyatnya bebas mengamalkan ajaran agama masing-masing. Sebilangan besar golongan ortodoks Islam telah mempersoalkan perkara tersebut kerana kecenderungan mereka untuk mengubah Indonesia menjadi sebuah negara Islam. Namun begitu, penentangan ini akhirnya telah dipatahkan pada dekad 1960-an. Selain itu, rukun kedua Pancasila, iaitu "Kemanusiaan yang Adil dan Beradab" membawa erti seseorang itu perlu memperlakukan orang lain secara adil, bebas daripada tekanan dan tidak membeza-bezakan suku, keturunan, agama dan lainnya. Maksud lainnya ialah semua orang harus menjunjung tinggi nilai kemanusiaan, dan berani melawan ketidakadilan. Rukun ketiga, "Persatuan Indonesia" membawa maksud komitmen untuk menyatukan lebih tiga ratus suku bangsa di Indonesia. Justeru, rakyat Indonesia harus mempunyai rasa cinta terhadap tanah airnya serta rela berkorban apabila diperlukan.

Rukun keempat dalam Pancasila, iaitu "Hikmat kebijaksanaan dalam permusyawaratan perwakilan" menggambarkan erti musyawarah dan muafakat yang merupakan ciri khas bangsa Indonesia. Persetujuan dan kesepakatan bersama dilakukan dengan akal sihat dan sesuai dengan hati nurani yang luhur. Rukun yang terakhir iaitu "Keadilan sosial bagi seluruh rakyat Indonesia", bermaksud sikap adil terhadap sesama masyarakat dan keseimbangan antara hak dengan kewajipan harus dikembangkan.

Era Orde Lama turut diwarnai perubahan sistem politik, iaitu daripada sistem politik yang liberal (1950-1959) kepada sistem politik berparlimen dan kemudiannya kepada demokrasi terpimpin (1959-1965). Pada masa sistem politik terpimpin diamalkan, Presiden 
Sukarno mengeluarkan istilah Nasakom, membawa erti Nasionalis, Agama, dan Komunis. Keadaan ini memaksa pembikin filem terpecah dua mengikut fahaman masing-masing iaitu Lekra (Lembaga Kebudayaan Rakyat) dengan tokohnya antara lain Bachtiar Siagian; dan Lesbumi dengan ketokohan Usmar Ismail dan Djamaludin Malik. Pada tahun 1955-1965, golongan kiri menghasilkan 40 buah filem manakala saingan mereka hanya menghasilkan 14 judul filem (Nugroho, 2015: 115).

Selepas Soeharto mengambil alih pemerintahan politik Indonesia pada tahun 1966, beliau telah menyusun semula institusi pawagam di bawah pentadbiran yang lebih berpusat iaitu di bawah Jabatan Penerangan. Kesusasteraan dan teater yang dianggap sebagai 'seni' turut diletakkan di bawah Jabatan Pendidikan dan Kebudayaan manakala pawagam pula dikelompokkan bersama-sama dengan radio dan televisyen komunikasi massa. Undangundang Filem Indonesia, no. 8/1992 telah menetapkan bahawa filem berfungsi untuk "mengembangkan kebudayaan kebangsaan sebagai aspek utama untuk meningkatkan keselamatan negara dalam pembangunan negara." Dalam paradigma pembangunan, filem mempunyai persamaan dengan tentera yang berpotensi mewujudkan suasana tidak stabil. Kesannya filem-filem tempatan dipantau dan ditapis dengan lebih ketat berbanding filemfilem yang diimport. Sebagai contoh, pembikin filem terlebih dahulu menyerahkan skrip kepada Badan Sensor Filem Indonesia sebelum proses penggambaran boleh dimulakan (Paramaditha, 2011).

Pada tahun 1977, Badan Sensor Filem Indonesia menguatkuasakan suatu panduan yang melarang pembikinan filem yang mengandungi unsur seks dan keganasan, kolonialisme, imperialisme, fasisme, sosialisme dan komunisme. Larangan ini turut dikenakan kepada beberapa filem yang telah pun selesai pembikinannya. Antaranya termasuklah filem arahan Syumandjaya, Yang Muda Yang Bercinta (1977). Filem ini dianggap menyesuaikan dan menerapkan teori revolusi dan kontradiksi fahaman komunis yang telah dilarang di Indonesia (Aartsen, 2011).

Penapisan ialah aspek yang paling ketara dalam tindakan pengawalan serta pemantauan kerajaan Indonesia terhadap bentuk dan kandungan yang mengambil kira kepentingan awam. Setiap filem mesti diluluskan oleh Lembaga Penapisan Filem (Badan Sensor Filem atau BSF) sebelum mendapat kebenaran tayangan. Sehingga pertengahan 1980-an, perhatian tertumpu pada monopoli filem import kerana sering menyentuh aspek penapisan dan pemantauan. Prapenapisan dijadikan sebagai syarat pengeluaran yang membezakan filem-filem Indonesia dengan yang lain. Ditubuhkan sejak era Belanda, Badan Sensor Filem (BSF) ialah institusi tertua yang bertanggungjawab dengan aktiviti pemantauan dan penapisan secara berterusan di panggung-panggung wayang Indonesia. Walau bagaimanapun, BSF hanya satu peringkat dalam peraturan kaedah kawalan negara yang dihasilkan untuk pemantauan filem tempatan.

Selain itu, filem memerlukan kelulusan daripada Direktorat Filem Jabatan Penerangan sebelum penggambaran boleh dimulakan. Setelah selesai penggambaran, salinan filem perlu diserahkan kepada badan ini sebagai panduan tentang sebarang kemungkinan yang melibatkan penyuntingan. Sekatan ini diperkenalkan pada tahun-tahun awal Orde Baru (Moran, 2005:176) lantaran kekhuatiran kerajaan terhadap sebarang elemen dalam filem yang boleh menggugat kestabilan perpaduan dalam masyarakat atau konflik yang boleh mewujudkan ketegangan sosial di Indonesia pada ketika itu. Justeru, sebarang elemen yang dirasakan boleh menyentuh isu sensitif, melukakan perasaan etnik tertentu, mengancam 
Islam serta mempunyai potensi ke arah mewujudkan ketidakinginan pemerintah mesti dipotong dan dilarang penayangannya (Sen \& Hill, 2001: 164).

Seperti yang dinyatakan, antara filem yang telah siap pembikinannya tetapi dilarang untuk ditayangkan ialah filem arahan Syumandjaya - Yang Muda Yang Bercinta (1977) yang turut dibintangi oleh penyair besar Indonesia W.S Rendra. Meskipun sudah lulus di bahagian penapisan dengan potongan babak sehingga 18 minit, filem ini telah dilarang untuk diedarkan dan disiarkan pada bulan Mei 1978 di wilayah hukum Kodam Jaya kerana dianggap terdapat unsur propaganda yang boleh menghasut masyarakat khususnya generasi muda. Masalah ini dianggap cukup serius sehingga dibicarakan pada peringkat Komando Operas Pemulihan Keamanan dan Ketertiban Indonesia Kopkamtib. Namun begitu, filem ini akhirnya mendapat kelulusan untuk penayangan di Jakarta pada September 1993.

Daripada penggunaan bintang filem asing serta banyaknya tindakan protes terhadap lembaga penapisan, kebijaksanaan badan penapisan filem di Indonesia dipersoalkan dan dikatakan sangat longgar terhadap filem-filem nasional. Tindakan yang dilakukan oleh LSF nampak seperti mendukung industri filem di Indonesia agar berkembang dengan cara memberikan kebebasan lebih terhadap para produser. Dengan melihat kecenderungan penapisan seperti ini, tampak bahawa kebijaksanaan badan penapisan selalu berada dalam kondisi pendulum, berayun ke kanan atau ke kiri yakni tidak mempunyai pendirian dan hanya mengikuti kehendak dan kepentingan pasaran filem nasional terutama kehendak pemerintah. Apabila pasaran filem nasional mengalami kesulitan dan sukar untuk menjual produk mereka, maka badan penapisan akan cenderung untuk melonggarkan syarat, terutama yang berunsurkan seks. Namun begitu apabila pasaran filem berada dalam keadaan baik, kandungan seks diharamkan sama sekali (Sasono, 2011). Retorik pemerintah begitu menekankan penapisan filem bagi melindungi masyarakat yang buta huruf yakni masyarakat yang dikelaskan sebagai penonton yang berpotensi untuk dipengaruhi oleh filem-filem yang membawa konteks negatif dan tidak diingini negara. Filem Di Bawah Lindungan Kaabah yang diangkat daripada novel nukilan seorang pemimpin Islam, Hamka, dianggap sebagai filem politik Islami oleh pihak berkuasa menyebabkan filem tersebut dilarang untuk ditayangkan sebelum Pilihan Raya 1988 (Sen, 2009: 13).

Terdapat banyak perkembangan baharu dalam dunia perfileman Indonesia semasa dan selepas reformasi. Pada tahun 1998, banyak peraturan dan sekatan kerajaan Soeharto yang berkaitan dengan pengeluaran filem dan pameran menjadi tidak sah. Selalunya, mereka yang masih ada diabaikan. Pada masa Presidensi Abdurahman Wahid (19992001), Kementerian Informasi telah dimansuhkan secara rasmi, tetapi Lembaga Pengawas Filem (pada tahun 1997 telah berubah menjadi Lembaga Sensor Filem (LSF) dikekalkan kedudukannya, walaupun kedudukannya dipertikai. Euforia dan gangguan Reformasi dan proses mentakrifkan semula struktur lama dan struktur juga memajukan kemajuan dalam dunia filem (Heeren, 2007).

Selepas rejim Soeharto berakhir, Indonesia menyaksikan sejenis kebangkitan Islam iaitu kesan daripada penindasan Islam oleh Orde Baru bagi mencegah Islam radikal daripada merosakkan imej sebuah negara membangun yang stabil dan moden. Terdapat sekurang-kurangnya dua kesan besar daripada kebangkitan ini. Pengaruh yang kian meningkat dalam politik membolehkan tindakan diambil terhadap pengisian pornografi dalam filem melalui Undang-Undang Pornografi. Di samping itu, kemunculan kebudayaan Islam yang kian mendominasi media lebih kelihatan yang bersesuaian dengan budaya 
pengguna di Indonesia (Paramaditha, 2012). Selain LFS, terdapat banyak lembaga kemasyarakatan yang bertindak melaksanakan tindakan 'menapis' dengan memprotes filem yang tidak disetujui mereka. Perkara ini meletakkan pengeluar filem berada dalam situasi yang sukar kerana perniagaan mereka terancam. Protes yang dilakukan dilihat melampaui batas dan menganggu ketenteraman awam. Mereka bertindak menggunakan ancaman kekerasan terhadap pekerja-pekerja bahagian perfileman sehingga menimbulkan perasaan takut dan gerun dalam kalangan pekerja.

Selain itu, protes yang dilakukan dengan ancaman kekerasan ini juga menyebabkan terjadinya ketidakpastian dalam kalangan ahli perniagaan dalam bidang perfileman. Dua organisasi kemasyarakatan yang paling banyak melakukan protes terhadap filem dalam beberapa tahun kebelakangan ini ialah Majelis Ulama Indonesia (MUI) dan Front Pembela Islam (FPI), terutama terhadap filem-filem yang dianggap mengandungi adegan seks yang lucah, atau dianggap melakukan penghinaan terhadap agama. Selain itu, golongan agamawan juga kerap melakukan protes berkaitan dengan filem-filem yang dianggap berupaya merosakkan moral masyarakat dan menggambarkan agama secara keliru (Sasono, 2011).

Untuk menunjukkan contoh bagaimana ideologi Pancasila dipaparkan dalam filem, analisis tekstual terhadap empat contoh filem dilakukan. Empat filem tersebut ialah Ketika Cinta Bertasbih (2009), Negeri Lima Menara (2012), Get Married (2007), dan Ada Apa Dengan Cinta (2002). Kaedah analisis tekstual amat penting kerana dengan analisis tekstual dapat dilakukan proses "to explore' (menggali lebih dalam), "to unpack" (untuk membuka yang tersembunyi), "to deconstruct" (membongkar konsep, nilai, ideologi, budaya, mitos, dan lainnya yang diproduksi dan direproduksi oleh pembuat teks atau penguasa media), "to understand" (untuk memahami bagaimana sebuah kultur, mitos, kepentingan dan lainnya yang ada dalam proses produksi teks) dan sebagainya (Ida, 2004: 67).

\section{Ketika Cinta Bertasbih (2009)}

Filem ini berkisarkan perjuangan seorang mahasiswa Indonesia yang melanjutkan pelajaran di Universiti Al Azhar, Kaherah selama 9 tahun. Sepanjang berada di sana, beliau bekerja sebagai pembuat tauhu demi menyara hidup ibu dan adik-beradiknya. Dalam filem ini juga diceritakan perjalanan tokoh utamanya, iaitu Khairul Azzam dalam mencari pasangan hidup bersesuaian dengan nilai agama Islam. Filem ini merupakan salah satu filem yang membawa trend baru iaitu filem Islami, yang dimulakan beberapa tahun sebelumnya menerusi filem Ayat-Ayat Cinta. Kedua-dua filem ini telah diadaptasi daripada novel bestseller karya Habiburrahman El Shirazy. Berbeza dengan filem Ayat-Ayat Cinta yang menggunakan pelakon terkenal, filem Ketika Cinta Bertasbih menggunakan pelakon-pelakon baharu yang diambil menerusi uji bakat di beberapa buah kota di Indonesia. Antara penekanan yang diambil kira ketika pemilihan pelakon berlangsung ialah kemampuan membaca Al-Quran dan pengetahuan agama Islam yang menjadi salah satu faktor penting yang digunakan sebagai elemen pemaparan utama dalam filem ini.

Selain itu, dari segi pemaparan visual, filem ini banyak mengandungi nilai Pancasila khasnya rukun pertama, iaitu Ketuhanan Yang Maha Esa. Sebagai contoh, filem ini banyak memberikan pengajaran mengenai konsep ketakwaan kepada Allah dan kewajaran untuk mematuhi segala ajarannya. Kepatuhan terhadap konsep takwa ditampilkan menerusi amalan individu yang mematuhi segala ajaran Allah dan menghindari segala larangannya. Sebagai contoh, watak Khoirul Azzam yang membantu Anna Althafunisa dan rakan- 
rakannya ketika dirompak di dalam sebuah bas merupakan suatu perlakuan yang adil dan beradab. Selain itu, filem ini turut menampilkan rukun ketiga Pancasila iaitu Persatuan Indonesia menerusi pemaparan peraduan yang kukuh dalam kalangan rakyat Indonesia khasnya ketika rakan mereka dirawat di hospital. Dalam filem, wujud beberapa dialog oleh watak utama, Khoirul Azzam, dan watak sampingan K.H. Luthfi Hakim mengenai ketuhanan dan kemanusiaan.

\author{
"Mbaknya sudah shalat?" \\ "Setiap orang mempunyai prinsip dalam hidupnya berdasarkan apa yang dia \\ yakini kebenaramya." \\ "Mengutamakan orang lain dalam hal ibadah hukumnya makruh." \\ "Kamu tidak usah mikir itu, biar kami yang urus."
}

(Khoirul Azzam)

\begin{abstract}
"Seorang suami harus mampu mengarahkan istrinya menuju kebaikan baik di dunia maupun di akhirat."
\end{abstract}

(K.H Luthfi Hakim)

Dalam filem Ketika Cinta Bertasbih, banyak dilihat dialog yang berkaitan dengan ajaran Islam. Misalnya, jemputan untuk menunaikan solat. Selain itu, pemaparan prinsip Islam yang sering mengingatkan agar penganutnya selalu menjaga kesucian terutama dalam hubungan antara lelaki dengan perempuan. Misalnya, nasihat dan teguran yang diberikan oleh Khoirul Azzam ketika gadis yang dicintainya dilamar oleh orang lain. Pemaparan yang menekankan ajaran Islam antara turut meliputi nasihat yang disampaikan Luthfi Hasan, yakni ayah kepada Anna Althafunisa yang menyentuh isu pencarian calon suami yang boleh membimbing kepada kebaikan di dunia dan akhirat.

Nilai kemanusiaan juga dapat ditemukan dalam dialog ketika salah seorang rakan serumah Azzam dimasukkan ke hospital dan tidak mempunyai wang untuk membiaya bil perubatan. Justeru, Azzam dan rakan-rakannya secara berkumpulan membiayai dan menanggung yuran perubatan tersebut. Nilai keadilan sosial menerusi amalan kerja keras turut dilihat menerusi watak Azzam yang sanggup memasak juadah makanan yang dipesan Eliana iaitu Soto Lamongan. Selain itu, persembahan Tari Saman yang dipentaskan di Kaherah berjaya mempamerkan rasa cinta terhadap budaya tanah air. Nilai kerja keras juga ditonjolkan ketika adegan Azzam sedang menguli kedelai menjadi tempe - suatu pekerjaan yang dilakukan oleh watak Azzam demi menyara ibu dan adik-adiknya di Indonesia. Secara visual, oleh sebab filem ini berbentuk keagamaan atau filem dakwah, terdapat banyak adegan yang menggambarkan suasana masjid dan juga pondok pesantren. Di samping itu, banyak adegan karakter utamanya sedang melaksanakan solat dan mengaji dipaparkan dalam filem ini. 


\section{Negeri Lima Menara (2012)}

Filem ini merupakan adaptasi novel yang turut menggunakan judul yang sama karya Anwar Fuady. Filem ini mengisahkan Alif seorang anak kelahiran Sumatra Barat yang diminta ibunya untuk pergi ke pesantren (sekolah pondok) di Jawa untuk tujuan menuntut ilmu, meskipun Alif ingin menyambung pengajiannya di sekolah umum. Alif mengambil masa yang panjang untuk membiasakan diri di sekolah pondok kerana terdapat jurang perbezaan antara sekolah pondok dengan sekolah umum terutama dari segi peraturan. Dalam proses tersebut, Alif telah berkenalan dan bersahabat rapat dengan lima kenalan baharu yang berasal dari tempat yang berbeza; Baso dari Gowa, Atang dari Bandung, Raja dari Medan, Said dari Surabaya, dan Dulmajid dari Madura. Mereka berenam selalu berkumpul di menara masjid dan dikenali sebagai Sahibul Menara yang bermaksud para pemilik menara. Mereka mempunyai cita-cita untuk mengunjungi lima menara di setiap pelosok dunia dan salah satunya ialah Big Ben di London yang pada akhirnya menjadi realiti.

Terdapat banyak nilai Pancasila yang dipaparkan dalam filem ini. Misalnya rukun pertama iaitu Ketuhanan Yang Maha Esa jelas terpapar menerusi penekanan terhadap pendidikan agama di pesantren. Selain itu, rukun kemanusiaan yang adil dan beradab dapat dilihat menerusi pemaparan watak Gowa yang rela berhenti belajar dan pulang ke kampung kerana ingin menjaga neneknya yang sakit. Begitu juga pengorbanan seorang ayah yang rela menjual satu-satunya kerbau miliknya demi membiayai anaknya yang akan bersekolah di luar kota. Tema Persatuan juga diperlihatkan semasa para pelajar di pesantren yang terdiri daripada kepelbagaian suku dan bangsa bersama-sama menonton dan menyokong pasukan Indonesia dalam perlawanan badminton Piala Thomas. Keadaan ini menunjukkan semangat nasionalisme yang tinggi dan ditonjolkan dengan berkesan walaupun mereka datang daripada latar bangsa yang berbeza. Tema kerakyatan yang dipimpin oleh hikmat kebijaksanaan diperlihatkan daripada sikap seorang pegawai yang terpaksa menerima hakikat bahawa anaknya gagal untuk masuk ke pesantren walaupun beliau mempunyai hubungan yang baik dengan pihak atasan. Nilai Pancasila lain ialah pengorbanan yang dipamerkan oleh para pengajar di pesantren yang sanggup mengajar secara percuma kerana menyebarkan ilmu itu merupakan suatu amalan yang lebih penting.

“Hidup seperti itu nak, jalani baru kita tahu mana yang paling baik untuk hidup kita."

(Ayah Alif)

"Gerakan atau pertumbuhan itu datangnya dari kalian sendiri. Itu yang namanya pemerintahan yang bottom up."

(Kyai Rais)

"Ingat bukan yang paling tajam tetapi yang paling bersungguh-sungguh."

(Ustadz Salman)

"Mimpi itu harus jauh, tinggi, liat menara itu sampai ke langit."

"Para Ustad menganggap di sini adalah ladang perjuangan bukan ladang penghidupan."

(Ustad Khalid) 
Terdapat nilai kerakyatan yang dapat dilihat dengan jelas menerusi beberapa dialog dalam filem ini. Misalnya, ketika watak ayah berusaha meyakinkan watak Alif untuk menjalani dulu kehidupan di pesantren meskipun keinginan sebenar alif lebih terarah menyambung pengajian ke sekolah umum. Nilai ini juga terlihat menerusi watak Kyai Rais yang memberikan analogi mengenai sistem pemerintahan negara ketika aduan mengenai penjana kuasa yang bermasalah dikemukakan. Nilai kemanusiaan turut dinyatakan dalam dialog antara Alif dengan ustaznya mengenai pembayaran percuma di Pesantren berdasarkan anggapan keluhuran dalam melakukan sesuatu perbuatan yang baik. Selain itu juga ada nilai suka bekerja keras seperti ucapan 'Man Jadda Wa Jadda' dan perlakuan ini terpamer menerusi dialog Baso tentang cita-cita yang harus digantungkan setinggi langit.

Dari segi visual, filem yang berlatarbelakangkan pesantren ini banyak menampilkan adegan yang menunjukkan kesungguhan dan kerja keras. Misalnya, watak Alif dan temantemannya membaiki penjana kuasa yang rosak. Sikap berdisiplin yang diperlihatkan menerusi watak Alif turut dipamerkan ketika ke masjid untuk bersolat. Semangat berpersatuan turut menonjol dalam adegan watak Alif meyakinkan para ustaz untuk menonton siaran langsung Piala Thomas di televisyen. Walaupun terdapat halangan pada mulanya, semangat berpersatuan sebagai bangsa Indonesia, Alif dan rakan-rakannya berjaya mendapat keizinan oleh Ustaz untuk menonton perlawanan tersebut. Dalam pada itu, pakaian yang dikenakan oleh pelajar dilihat lebih moden dan menepati nilai-nilai Islam yang tidak hanya mementingkan agama semata-mata.

\section{Get Married (2007)}

Filem Get Married (2007) diarahkan oleh Hanung Bramantyo yang berkisar mengenai empat sahabat iaitu Mae, Guntoro, Eman, dan Beni yang merupakan sahabat sekampung yang erat. Plot cerita ini berkembang menerusi pengkisahan Mae yang dicarikan jodoh oleh orang tuanya. Malangnya, setiap calon yang datang selalu diganggu oleh sahabatsahabatnya. Namun begitu, kehadiran Rendy yang tampan dan berasal daripada keluarga kaya telah mendorong Mae untuk berkahwin. Akibat salah faham, Rendy telah dipukul oleh teman-teman Mae sehingga mengakibatkan Rendy dan teman-temannya daripada perumahan kaya ingin membalas dendam dan mencetuskan perkelahian dengan warga kampung. Filem ini dianggap berjaya dan ditonton lebih dari satu juta penonton.

Dalam filem ini terdapat nilai Pancasila, misalnya pada rukun kedua, Kemanusiaan yang Adil dan Beradab yakni wujudnya persamaan hak meskipun berbeza status sosial. Mae dan Rendy ialah dua manusia yang berasal daripada status sosial yang berbeza. Mae berasal dari keluarga miskin dan menetap di kampung manakala Rendy berasal daripada keluarga kaya dan tinggal di kawasan elit bandar. Kedua-dua mereka saling mencintai dan memutuskan untuk berkahwin. Sila Persatuan juga terlihat berdasarkan perpaduan warga kampung ketika diserang oleh warga perumahan elit dan mereka bersedia untuk berkorban demi menjaga kehormatan kampung. Rukun kelima dalam Pancasila iaitu Keadilan sosial bagi seluruh rakyat Indonesia tercermin dalam acara pernikahan Mae menerusi kehadiran penduduk kampung dan bandar yang membantu majlis pernikahannya secara gotong royong. Namun begitu, secara umum, filem ini juga menggambarkan keadilan sosial yang belum tercipta di Indonesia dengan kewujudan pengangguran walaupun mereka sudah menyelesaikan pendidikan tinggi. 
"Gaji memang kecil tapi saya rajin kasih les"

(Ramlan)

"Yang pakai kekerasan hanya orang primif"

(Rendy)

"Pendidikan orang sini memang tidak ada yang tinggi tetapi disini tidak ada yang nyolong, rampok, apalagi korupsi"

(Orang Kampung)

Dialog mengenai gaji guru kecil merupakan sindiran kepada gaji guru di Indonesia yang kecil sehingga belum memenuhi asas keadilan. Asas keadilan juga tampak pada dialog Rendy kepada teman-teman Mae yang ingin memukulnya dan mengatakan bahawa mereka yang menggunakan kekerasan hanya dalam kalangan orang primitif. Prinsip kemanusiaan juga tampak ketika kampung tempat Mae bermukim akan diserang oleh anak-anak kaya teman Rendy, salah satu orang kampung yang tidak berasa bersalah menyindir orangorang kota yang walaupun berpendidikan tinggi tetapi suka melakukan tindakan rasuah yang bertentangan dengan nilai kemanusiaan.

Secara visual, filem ini menggambarkan ketinggian jurang sosial dan kelemahan keadilan sosial bagi seluruh rakyat Indonesia. Visual kampung yang tidak bersih ditonjolkan sangat berbeza dengan visual kawasan perumahan elit tempat Rendy tinggal. Begitu juga dengan adegan perbandingan motor berkuasa besar yang berselisih jalan dengan penjual yang menggunakan gerobak. Sisi positif daripada filem ini masih ditemukannya dengan penonjolan nilai-nilai kemanusiaan, terutama di kampung. Pada saat pesta perkahwinan, jiran-jiran datang untuk membantu tuan rumah. Dalam adegan ini juga ditemukan aspek kecintaan kepada tanah air dengan menampilkan kesenian ondel-ondel dari Betawi yang biasa menjadi pengiring pengantin.

\section{Ada Apa dengan Cinta (2002)}

Filem Ada apa dengan Cinta ialah produksi tahun 2002 arahan Rudi Soedjarwo dan dianggap sebagai pembangkit filem nasional yang dianggap mati suri pada dekad 1990-an. Filem ini bercerita tentang Cinta yang menguruskan maklumat persekolahan di dinding sekolah bersama sahabatnya seperti Milly, Karmen, Alya dan Maura. Persahabatan yang rapat ini berubah ketika Cinta bertemu dengan Rangga, iaitu seorang watak yang angkuh dan dingin. Percintaaan Rangga dan Cinta menyebabkan Cinta mulai memisahkan diri daripada kumpulannya dan membawanya masuk ke dunia lain yang belum pernah dirasakan sebelumnya. Filem ini secara naratifnya merupakan filem remaja. Walaupun ceritanya ringan, filem popular ini masih mengandungi elemen moral yang ingin disampaikan oleh pengarahnya. Nilai-nilai Pancasila yang dapat kita temukan pada rukun kedua Pancasila terpamer menerusi watak Alya bersama ibunya yang menjadi mangsa keganasan rumahtangga oleh ayahnya sendiri. Ini menyebabkan Alya telah melakukan percubaan untuk membunuh dirinya. Cinta dan teman-temannya menunjukkan rasa kemanusiaannya dengan mendengar keluhan Alya dan membantunya ketika Alya dirawat di rumah sakit. 
Dalam filem ini juga terkandung rasa cinta akan tanah air melalui kesedaran mencintai bahasa Indonesia. Rasa cinta ini ditonjolkan menerusi pertandingan puisi. Nilai-nilai kemanusiaan yang berani membela kebenaran juga dapat dilihat melalui watak dan perwatakan ayah kepada Rangga yang berani menulis tesis mengenai rasuah dalam pemerintahan sehingga keselamatan dirinya sering terancam.

"Masalah salah satu diantara kita adalah masalah kita semua."

"Bila emosi mengalahkan logika, terbuktikan banyakan ruginya."

(Cinta)

"Kita memiliki kekayaan yang tidak ternilai harganya yaitu bahasa Indonesia."

(Pak Taufik)

"Tahun 96 tulis tesis tentang kebusukan bisnis orang-orang pemerintahan. Sama juga cari mati."

(Rangga)

Dialog dan visual dalam filem banyak mencerminkan nilai-nilai Pancasila. Sebagai contoh, rasa cinta akan tanah air mengenai bahasa dan nilai kemanusiaan khasnya ketika Cinta meyakinkan Alya bahawa dia akan memberikan bantuan sepenuhnya sekiranya keganasan fizikal yang dilakukan oleh ayahnya berulang. Dalam hal ini amat jelas ditekankan mengenai nilai setia kawan yang memberikan tumpuan kepada peranan Cinta dan kawan-kawannya untuk membantu Alya. Kepentingan bahasa Indonesia juga ditunjukkan ketika Pak Taufik, Guru Besar sekolah Cinta dalam pidatonya menekankan kepentingan penggunaannya dalam pertandingan mencipta puisi. Baju batik yang dikenakan oleh Pak Taufik sebagai pakaian rasminya dianggap suatu lambang cinta terhadap kebudayaan Indonesia. Dalam dialog yang lain, Rangga mempersoalkan Cinta dan kawan-kawannya yang gemar menggunakan bahasa slanga berbanding bahasa Indonesia rasmi. Nilai keberanian yang disampaikan oleh Yusrizal iaitu ayah kepada Rangga turut ditonjolkan menerusi tindakannya yang berani membongkar salah laku pemerintahan oleh rejim Orde Baru melalui tesisnya. Selain itu, keberanian Rangga yang mengejar pengganas dan menyelamatkan orang yang disayanginya daripada kebakaran boleh dianggap suatu bentuk kasih sayang terhadap keluarga.

\section{KESIMPULAN}

Pancasila merupakan falsafah hidup bangsa Indonesia yang nilai-nilainya sudah wujud jauh sebelum Indonesia merdeka pada tahun 1945. Pancasila yang diwujudkan secara rasmi pada 1 Jun 1945 merupakan simbol penyatuan Indonesia, sebuah negara besar yang mempunyai masyarakat pelbagai bangsa dan budaya. Salah satu medium kuat dalam pemeliharaan dan penyampaian nilai pancasila ini dilakukan menerusi pelbagai medium khasnya budaya popular seperti filem. Kewujudannya sejak 1926, menyaksikan filem Indonesia mengalami perkembangan dari masa ke masa. Pengukuhannya amat jelas kelihatan pada era Orde Baru, ketika pemerintahan Presiden Soeharto. Dengan peningkatan populariti filem, pemerintah Orde Baru telah menghasilkan pelbagai filem ideologi yang dan sarat dengan mesej dari pemerintah. Namun begitu, selepas kejatuhan Soeharto, para pembikin filem bebas menghasilkan filem meskipun masih di bawah pemantauan Lembaga Sensor Filem. Kebijaksanaan ini mendorong pertumbuhan pesat dan perkembangan kukuh filem nasional 
yang mempunyai elemen Pancasila yang jelas meskipun tidak dinyatakan secara langsung.

\section{RUJUKAN}

Aartsen, J. (2011). Film world Indonesia: The rise after the fall. Utrecht: Universitait Utrecht.

Abdullah, T., Ardan, S. M., Biran, M. Y., \& Dewan Film, N. (1993). Film Indonesia: bagian I: 1900-1950. Jakarta: Dewan Film Nasional.

Beck, D. M. C., \& Irawan, I. (2016). Islam, Pancasila And Value System OF Indonesian National Education. Jurnal Pendidikan Islam, 1(1), 1-23.

Biran, M. Y. (2009). Sejarah film, 1900-1950: Bikin film di Jawa. Jakarta: Komunitas Bambu. Budiman, A. (1990). State and civil society in Indonesia. Melbourne: Monash University.

Geertz, C., Mahasin, A., \& Rasuanto, B. (1983). Abangan, santri, priyayi: dalam masyarakat Jawa, Jakarta: Pustaka Jaya.

Hanan, D. (2017). Cultural Specificity in Indonesian Film: Diversity in Unity: Switzerland: Palgrave Macmillan

Heeren, K. v. (2007). Return of the Kyai: representations of horror, commerce, and censorship in post-Suharto Indonesian film and television 1. Inter-Asia Cultural Studies, 8(2), 211-226.

Heider, K. G. (1991). Indonesian cinema: national culture on screen. Honolulu: University of Hawaii Press.

Kaelan. (2002). Pendidikan Pancasila. Yogyakarta: Paradigma.

Kaelan. (2015). Liberalisasi ideologi negara Pancasila. Yogyakarta: Paradigma.

Khoo, G. C. (2011). Mau dibawa ke mana sinema kita? Beberapa wacana seputar film Indonesia. Jakarta: Salemba Humanika.

Moran, A. (2005). Film policy: International, national and regional perspectives. London: Routledge.

Nugroho, G. (2015). Krisis dan paradoks film Indonesia. Jakarta: Penerbit Buku Kompas.

Paramaditha, I. (2011). City and desire in Indonesian cinema. Inter-Asia Cultural Studies, 12(4), 500-512.

Paramaditha, I. (2011). Cinema, sexuality and censorship in post-Soeharto Indonesia. Dlm. Baumgartel, T. (ed). Southeast Asian independent cinema. Hong Kong: Hong Kong University Press.

Ramage, D. E. (2002). Politics in Indonesia: Democracy, Islam and the ideology of tolerance. London: Routledge.

Said, S. (1991a). Profil dunia film Indonesia. Jakarta : Pustakakarya Grafikatama.

Said, S. (1991b). Pantulan layar putih: film Indonesia dalam kritik dan komentar. Jakarta: Pustaka Sinar Harapan.

Sasono, E. (2011). Menjegal film Indonesia: pemetaan ekonomi politik industri film Indonesia. Jakarta: Perkumpulan Rumah Film dan Yayasan Tifa.

Sen, K. (2009). Kuasa dalam Sinema. Yogyakarta: Penerbit Ombak.

Sen, K., \& Hill, D. T. (2001). Media, budaya dan politik di Indonesia. Jakarta: Institut Studi Arus Informasi. 
Steenbrink, K. (2015). Pancasila as an ambiguous instrument for interreligious harmony and development in Indonesia, 1945-2015. Bulletin of the Nanzan Centre for Asia-Pacific Studies (10), 15-36.

Sudaryanto. (2007). Filsafat politik Pancasila: Refleksi atas teks perumusan Pancasila. Yogyakarta: Kepel Press.

Yamin, M. (1962). Tatanegara Madjapahit: Jaitu Risalah sapta parwa berisi 7 parwa hasil penelitian ketatanegaraan Indonésia tentang dasar dan bentuk negara Nusantara bernama Madjapahit, 1293-1525. parwa II, III. Jakarta: Jajasan Prapantja.

Yngvesson, D. (2015). Kuldesak and the inexorable pulp fiction of Indonesian film history. Indonesia and the Malay World, 43(127), 345-377. doi:10.1080/13639811.2015.1046756 